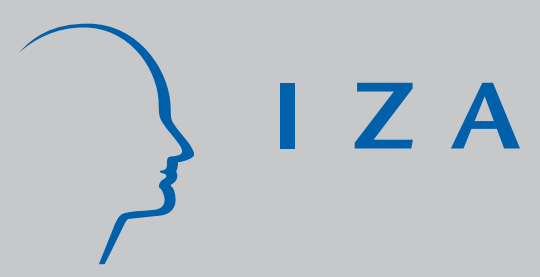

IZA DP No. 605

The Wage Policy of Firms - Comparative Evidence for the U.S. and Germany from Personnel Data

Christian Grund

October 2002 


\title{
The Wage Policy of Firms - Comparative Evidence for the U.S. and Germany from Personnel Data
}

\author{
Christian Grund \\ University of Bonn and IZA Bonn
}

\author{
Discussion Paper No. 605 \\ October 2002
}

\author{
IZA \\ P.O. Box 7240 \\ D-53072 Bonn \\ Germany \\ Tel.: +49-228-3894-0 \\ Fax: +49-228-3894-210 \\ Email: iza@iza.org
}

This Discussion Paper is issued within the framework of IZA's research area The Future of Labor. Any opinions expressed here are those of the author(s) and not those of the institute. Research disseminated by IZA may include views on policy, but the institute itself takes no institutional policy positions.

The Institute for the Study of Labor (IZA) in Bonn is a local and virtual international research center and a place of communication between science, politics and business. IZA is an independent, nonprofit limited liability company (Gesellschaft mit beschränkter Haftung) supported by the Deutsche Post AG. The center is associated with the University of Bonn and offers a stimulating research environment through its research networks, research support, and visitors and doctoral programs. IZA engages in (i) original and internationally competitive research in all fields of labor economics, (ii) development of policy concepts, and (iii) dissemination of research results and concepts to the interested public. The current research program deals with (1) mobility and flexibility of labor, (2) internationalization of labor markets, (3) welfare state and labor market, (4) labor markets in transition countries, (5) the future of labor, (6) evaluation of labor market policies and projects and (7) general labor economics.

IZA Discussion Papers often represent preliminary work and are circulated to encourage discussion. Citation of such a paper should account for its provisional character. A revised version may be available on the IZA website (www.iza.org) or directly from the author. 
IZA Discussion Paper No. 605

October 2002

\section{ABSTRACT}

\section{The Wage Policy of Firms - Comparative Evidence for the U.S. and Germany from Personnel Data}

The wage policy of a German and a U.S. firm is comparatively analysed with a focus on the relation between wages and hierarchies. While prior studies examine only one particular firm, in this paper two plants of the same owners with similar production processes in different institutional environments are inspected. Convex wage profiles over the hierarchy levels of both plants are found. The U.S. plant shows considerably higher intensity of intra-firm competition in terms of higher intra-level wage inequality and yearly promotion rate. In contrast, wages are more distinctly attached to hierarchy levels in the German firm, as wage regressions show. The results are discussed in comparison to prior studies.

JEL Classification: M52, J31, M12

Keywords: hierarchies, intra-firm wages, personnel records

Corresponding author:

Christian Grund

University of Bonn

BWL II

Adenauer Allee 24-42

53113 Bonn

Germany

Tel.: +49228739213

Fax: +49 228739210

Email: christian.grund@uni-bonn.de 


\section{The Wage Policy of Firms - Comparative Evidence for the U.S. and Germany from Personnel Data}

\section{Introduction}

Do wage policies of firms correspond to pertinent theoretical economic approaches?

What are the decisive wage determinants within a firm? Can we observe differences in the wage policy of similar firms between countries with different institutional frameworks?

Much research is done in order to analyse wages of employees, using representative data sets from different countries. As to many important questions these data sets represent a fruitful fundament for research, but it is not possible to look inside the "black box" of a firm with these general data. In order to shed light into this black box, data from personnel records of single firms are needed. By using such records the examinations get the character of case studies, but the wage policy of firms can be analysed in more detail. The perils of possibly idiosyncratic results can be stemmed by trying to accumulate more data from different firms.

There are only few studies, which analyse the wage policy of single firms so far. Probably the best known are the contributions of Baker et al. (1993, 1994a, 1994b). ${ }^{1}$ They examine an U.S. service industry firm using the personnel records of this firm and confirm a convex hierarchical wage structure, for example. In 1995 the unsatisfactory status quo of poor empirical evidence concerning internal labour

\footnotetext{
${ }^{1}$ Another prominent study is the investigation of Lazear (1992), who analyses another firm and defines promotions as considerably high wage increases, but does not have a given organisational structure of that firm. With this approach it is not possible to explore the link between hierarchies and wages in detail.
} 
markets and the wage policy of firms was pointed out by Baker and Holmström (1995) with their title statement: "Too Many Theories, Too Few Facts”.

Since then the situation has changed slightly but not satisfactorily. Few recent papers make use of personnel records of single firms. ${ }^{2}$ Among these, some papers concentrate on the link between wage profiles and productivity profiles of employees within a firm, a question that was originally approached by Medoff and Abraham (1980). Lazear (1999) as well as Flabbi and Ichino (2001) find evidence for a single U.S., respectively Italian, firm that individual productivity does not rise as rapidly with tenure as wages do. Hence, evidence is found for the fact that deferred compensation is implemented in firms as a motivator, which is the key module of Lazear's model (1979) to explain mandatory retirement. ${ }^{3}$

Lazear (2000) reuses the data of his 1999 paper (Safelite Glass Corp.) in order to confirm that monetary incentives matter. The firm's productivity increased by approximately 40 percent in consequence of a rearrangement of the wage payment from hourly wages towards piece rates. Apart from the obvious direct incentive effect a selection effect - capable new employees joined the firm - was responsible for half of the overall effect as well.

Ariga et al. (1999) analyse the importance of an "early-starter effect", also known as "fast track", in a Japanese firm, which is characterised by sooner promotions of employees of an entry cohort on a certain level of the hierarchy, who has been promoted faster to this level as well. ${ }^{4}$ Chiappori et al. (1999) focus on the wage dynamics within a French firm and find relevance for a "late-beginner effect" next to

\footnotetext{
${ }^{2}$ The following list does not raise the claim to be exhaustive.

${ }^{3}$ There is some evidence, on the other hand, that learning and human capital is most important for wage increases at the lower bound of the hierarchy (see Flabbi and Ichino 2001 as well as Lima and Pereira 2001).

${ }^{4}$ See Baker et al. (1994a: 902) for evidence of the early-starter effect as well.
} 
the early-starter effect. The late-beginner effect describes the fact that controlling for the wage at date $t$ the wage at $t+1$ is negatively correlated with the wage at $t-1$.

Ransom and Oaxaca (2002) analyse personnel records of a U.S. grocery store chain and concentrate on sex differences in pay. They find evidence for the fact that women are discriminated against men in that firm. Although the amount of direct wage discrimination is economically not very important, women are disadvantaged to a considerable extent with regard to occupational segregation.

The only pertinent analysis of a German firm is the examination of the so called "South Factory" during the period of 1976 to 1984. Brüderl et al. (1991, 1992, 1993) examine intra-firm mobility patterns in particular. Because wage groups define hierarchy levels, they abstain from checking out the link between hierarchies and wages separately.

Most of the mentioned studies make use only of the data concerning a certain part of the firm's hierarchy. ${ }^{5}$ A recent exemption is the contribution of Treble et al. (2001), who replicate the analysis of Baker et al. (1994a) using personnel records of a British firm from the service sector. ${ }^{6}$ They confirm the main results of Baker et al., but ask for further data and results especially from manufacturing firms to manifest (or modify) the results for a broader variety of firms.

This demand is met with this paper. The wage policy of a U.S. and a German firm, which have the same owners and belong to the manufacturing sector, are analysed using the personnel records of two decades each. The focus of this study is on the link

\footnotetext{
${ }^{5}$ For example, Lazear $(1999,2000)$ only looks at one particular level - the glass installers - of Safelite. ${ }^{6}$ Another exemption is a paper by Seltzer and Merett (2000), who use the personnel records from the Union Bank of Australia in the late $19^{\text {th }}$ and early $20^{\text {th }}$ century. They confirm all important components of internal labour markets introduced by Doeringer and Piore (1971). This contribution is very interesting in terms of economic history, but is obviously inapplicable to describe the present wage policy of firms. Hence, it is neglected in the further discussion.
} 
between hierarchy levels and wages. ${ }^{7}$ In contrast to prior investigations, which use only data from one firm, the data are unique in the sense that a comparative examination of the two firms is possible. Discrepancies caused by different "types" of entrepreneurship can be neglected, since the U.S. and the German plant belong to the same five owners. In addition, identical technologies are used in the two plants.

Hence, possible differences caused by varying institutional frameworks between the U.S. and Germany can be approached within this study. ${ }^{8}$

The paper is organised as follows: In section 2, the data are described in detail. Section 3 presents the results, which focus on the link between hierarchies and wages. Additionally, the relevance of other possible wage determinants such as human capital variables is discussed. Section 4 offers a discussion of the results in comparison to prior studies and section 5 contains some concluding remarks.

\section{Data}

This empirical study is based on data of personnel records of one U.S. and one German firm. Both firms belong to the manufacturing sector and have very similar production processes. The data are confidential, so that neither the firms' nor the owners' names can be mentioned. Personnel records of 402 fulltime employees of the German plant can be analysed for the years 1975 to 1995 . Unfortunately it was not possible to get data of the whole workforce of this plant, since the personnel records were partly incomplete. ${ }^{9}$ In 1995 approximately 630 people were employed in this plant. There is information for sex, year of birth, year of entry in the firm and years of

\footnotetext{
${ }^{7}$ Additional aspects of the personnel policy such as hiring and promotions are analysed in Grund and Kräkel (2001).

${ }^{8}$ Kanemoto and MacLeod (1991) analysed labour management practices of different countries already theoretically.

${ }^{9}$ This problem refers mainly to employees of lower levels of the hierarchy.
} 
schooling as well as the monthly gross wage and the position within the hierarchy at the end of each year.

The sample of the U.S. firm includes data of all 214 employees, who worked fulltime for at least one year during the observation period from 1978 to 1998. The fact that this firm was founded in the early seventies accounts for the small number of employees during this decade, but the workforce constantly grew up to 179 employees in 1998. Except for the years of schooling the same information as in the German firm is available.

Both firms have been organised by the owners in a hierarchy with several levels. The German plant is divided into 13 hierarchy levels with different tasks. ${ }^{10}$ The two lowest hierarchy levels (12 and 13) consist of jobs, which tasks need only a short training period. Skilled (blue collar) workers can be found at hierarchy levels 11 to 5 . The executive and administration positions of the firm are based on the levels 4 to 1 , whereby the owners of the firm represent the top management (level 1).

The U.S. firm consists of 10 hierarchy levels. At the lowest - level 10 - workers are placed, who merely receive a short introduction into their tasks after recruitment. The tasks for workers on the other levels are more difficult. The higher the position within the hierarchy, the more on-the-job training is needed. On level 6, positions are located, which are not directly involved in the production process. Levels 4 and 5 consist of positions for skilled workers, who are responsible for planning the workflow. The top three levels represent management levels.

\footnotetext{
${ }^{10}$ Strictly speaking, there exist yet another level, the apprentices of the firm, who take part in the official German apprenticeship system with two days per week at a public and state financed occupational school and three days training on the job for two to three years. Wages for these apprentices are much lower than for "regular" employees and are normally fixed by collective wage agreements. These apprentices do not form part of the analysis.
} 
Most employees are placed at the levels 7 and 8 in the U.S. plant and at the levels 9 to 11 in the German plant (see Table 1). The strategic decisions for the U.S. firm are not made by its managing director, but by the owners of both firms, which are placed at level 1 of the German plant. The owners are excluded from the following analysis, because they are able to set their own wages in consideration of tax-based regulations, for example.

Table 1: Means of variables

\begin{tabular}{|l|c|c|}
\hline \multicolumn{1}{|c|}{ Variable } & German plant & U.S. plant \\
\hline Female & 0.071 & 0.121 \\
Age (years) & 37.13 & 36.09 \\
Tenure (years) & 14.08 & 6.77 \\
Years of Schooling* & 9,36 & - \\
\multicolumn{1}{|c|}{ Level-Dummies } & & \\
Level 1 & - & 0.020 \\
Level 2 & 0.029 & 0.034 \\
Level 3 & 0.023 & 0.065 \\
Level 4 & 0.024 & 0.070 \\
Level 5 & 0.019 & 0.104 \\
Level 6 & 0.026 & 0.075 \\
Level 7 & 0.079 & 0.419 \\
Level 8 & 0.045 & 0.181 \\
Level 9 & 0.231 & 0.026 \\
Level 10 & 0.143 & 0.006 \\
Level 11 & 0.208 & - \\
Level 12 & 0.119 & - \\
Level 13 & 0.054 & - \\
\hline
\end{tabular}

Note: *: Years of schooling is computed using information about the highest received schooling degree (no schooling degree $=7$, degree from "Hauptschule" $=9$, degree from "Realschule" $=10$, Abitur $=13$, college of higher education $=15$, university degree $=18$ ) .

Overall, the German (the U.S.) plant yields 5781 (1266) observations for the empirical analysis. Only 12 percent of the workforce in the U.S. firm is female and this fraction is even lower in the German plant ( 7 percent). The average of completed years of tenure in the German plant (14 years) is twice as high as in the U.S. firm. 
This is not surprising since the U.S. firm was founded in the seventies. In contrast, the average age is comparable in the two firms. The level of qualification in the German firm is remarkably low. ${ }^{11}$ Almost 80 percent of the workforce only received a degree from a "Hauptschule", which is the lowest general degree and can be received after nine years of schooling. Additional seven percent do not have any schooling degree.

\section{Evidence}

The aim of this study is to analyse and compare the wage policy in the two firms described above with a particular focus on the link between the hierarchy and wages. An important result of several theoretical approaches is an increasing (and convex) wage structure with regard to the hierarchy of a firm. Different explanations can be given for this kind of intra-firm wage inequality. First, in the sense of human capital theory, the demand of tasks and hence the necessary human capital is increasing across the levels of the hierarchy. This leads to higher wages because of higher productivity in higher positions (see already Becker 1962).

But an increasing hierarchical wage structure should be found even in the absence of varying tasks over the hierarchy. Typically, the effort of an employee does not only affect the individual's outcome, but also the outcome on subordinated levels of the hierarchy, which leads to a kind of multiplier effect (see Rosen 1982). Hence, employees should participate in productivity effects at lower hierarchy levels, for which they are responsible.

\footnotetext{
${ }^{11}$ As mentioned above, it was not possible to get information about years of schooling for all employees of the U.S. firm.
} 
Thinking of incentive problems, efficiency wages can help to avoid shirking, which is important especially at higher levels because of the multiplier effect. Then employees are deterred from shirking because of the possible loss of their efficiency wages. Increasing wage gains can be explained with this approach as well (see Becker and Stigler 1974, Calvo and Wellisz 1979, Calvo 1987).

If promotions within a firm correspond to tenure, hierarchical wage differentials can be established by deferred compensation as well. According to the bonding model of Lazear (1979), employees get wages below (above) their productivity at the beginning (end) of their intra-firm career. If the employee is not dismissed, he will get back his wage bond during the second half of his career at higher hierarchy levels.

Finally, hierarchical wage differentials can be explained by tournament theory (see Lazear and Rosen 1981). According to this theory, several employees of a certain hierarchy level with comparable tasks are faced in a rank order tournament and the winner is promoted to the next level of the hierarchy. The promotion has to be combined with a wage increase in order to induce incentives. Rosen (1986) shows within a dynamic tournament model that increasing wage premiums hierarchy upward make sense in the case of risk averse employees.

\section{Wages and Hierarchy}

Positive hierarchical wage differentials are to be expected in both plants due to several wage theories as discussed above, and partly even increasing wage differentials hierarchy upwards are derived theoretically. The hierarchical wage structure of both plants is shown in Figure 1 for the most recent years 1995 (German 
plant) and 1998 (U.S. plant) respectively. For both plants the resulting pictures are very similar for other years as well.

Figure 1: Ranges and mean values of gross monthly wages within hierarchy levels in the ...German plant (1995) ...U.S. plant (1998)
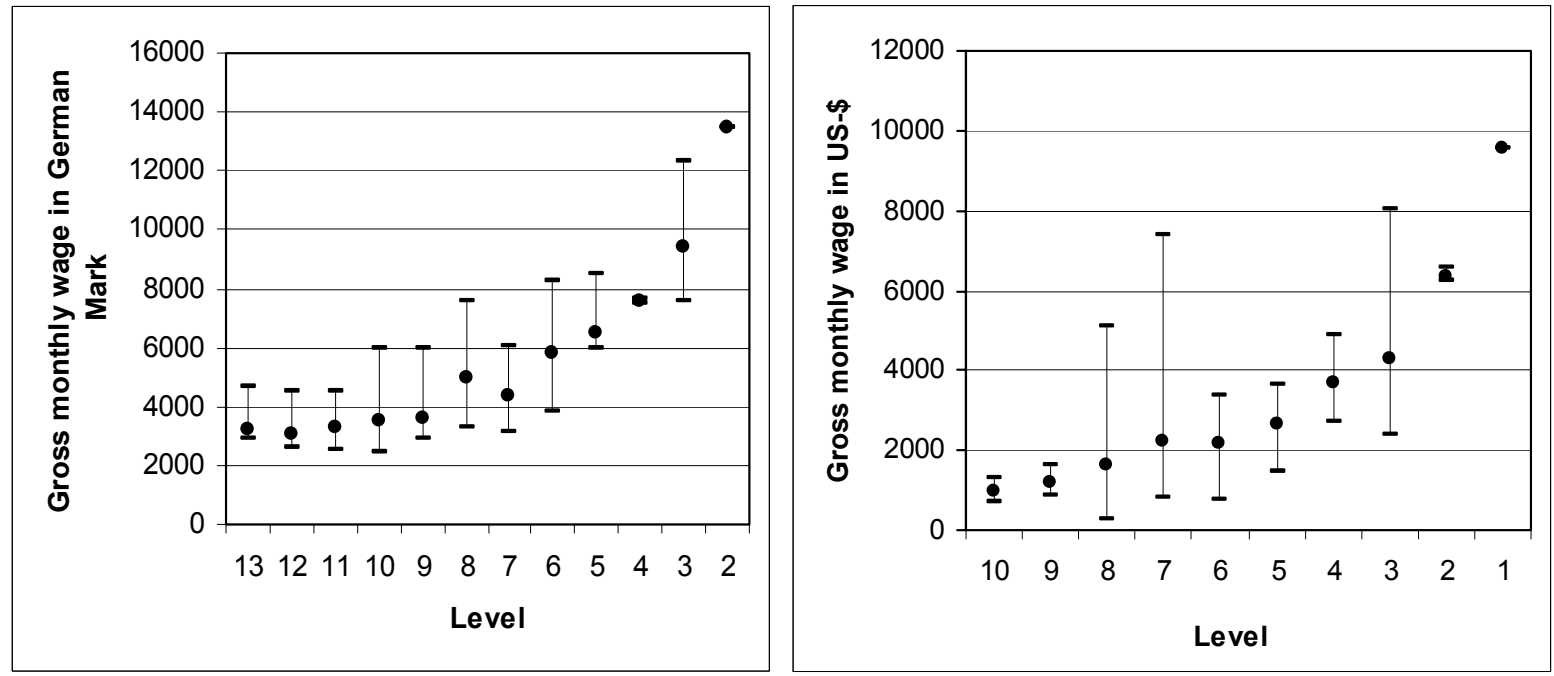

Note: $\bullet=$ mean wage within a certain level of the hierarchy. Level 1 of the German plant contains the owners of the company. Their "wages" are deleted from the analysis, because tax regulations determine their income setting and hence, generate biases. These five managing partners "allow themselves" a monthly income of DM 18,542 in 1995.

Although negative differences between the mean wages of level 13 and 12 as well as between level 8 and 7 are observable for the German plant, a convex wage structure for the firm as a whole is visible, because wage differences grow particularly between skilled workers and management levels. A convex wage structure is even clearer for the U.S. plant. There is only one negative wage difference between level 7 and 6, which is the level outside the main production process. Additionally, considerable ranges within some levels of the hierarchy can be elucidated with this picture especially for the U.S. plant. The pictures of Figure 1 are generally in line with the results of Baker et al. (1993: 373) and Treble et al. (2001: 544). Section 4 discusses the results of this study with those prior examinations in more detail. 


\section{Wage Inequality}

Wage inequality is an important question in personnel economics. Strictly speaking, there are no extrinsic performance incentives in a firm without any wage inequality, which encourage employees to make more than a certain minimum effort that is need to avoid a dismissal. This leads to the consideration that a high intra-firm wage inequality act as an indicator for the intensity of competition in the firm: First, differences between hierarchy levels induce performance incentives to attain a top position within the firm. ${ }^{12}$ Second, wage inequality within certain levels of the hierarchy caused by pay for performance can generate additional incentives.

A suitable measure to calculate the amount of wage inequality in a firm is the TheilIndex $(T)$, which is given by

$$
T=\frac{1}{n} \sum_{i=1}^{n} \frac{w_{i}}{\bar{w}} \ln \frac{w_{i}}{\bar{w}},
$$

where in this case of measuring wage inequality of one particular firm, $n$ is the number of employees in the firm, $w_{i}$ is the wage of person $i$ and $\bar{w}$ is the mean wage of the firm. The Theil-Index has the advantage to be additively decomposable in a simple way generating disjunctive subgroups $g$, which consist of the employees of the different hierarchy levels of the firm: ${ }^{13}$

$$
T=\underbrace{\sum_{g} \frac{n_{g}}{n} \frac{\bar{w}_{g}}{\bar{w}} \ln \frac{\bar{w}_{g}}{\bar{w}}}_{\text {Inter - Theil }}+\underbrace{\sum_{g}\left(\frac{n_{g} \bar{w}_{g}}{n \bar{w}} \cdot \frac{1}{n} \sum_{i=1}^{n_{g}} \frac{w_{i}}{\bar{w}} \ln \frac{w_{i}}{\bar{w}}\right)}_{\text {Intra - Theil }}
$$

\footnotetext{
${ }^{12}$ In the strict sense, this statement does only hold as long as the higher wages outweigh possible costs of increasing effort at higher positions in the hierarchy.

${ }^{13}$ See Theil (1967: 95) and Shorrocks (1980: 613) for the decomposition of the Theil Index. The qualitative results of the amount of inequality hold for other measures, i.e. the Gini-Index or different percentile ratios, as well.
} 
Here, $n_{g}$ and $\bar{w}_{g}$ stand for the number of employees and the mean wage of level $g$. The wage inequality is decomposed in two parts: the first part describes wage variations between the levels of the hierarchy (Inter-Theil) and the second part explains wage dispersions within the hierarchy levels (Intra-Theil). Intra-Theil is characterised as the weighted sum of the particular Theil-Index within the levels using the share of the firms wage sum in the corresponding level as weights.

Table 2 shows the amount of wage inequality for the German firm in the years 1975, 1985 and 1995, as well as for the U.S. firm in the years 1996, 1997 and $1998 .^{14}$ The wage inequality in the German firm increased slightly during the observation period (see Table 1). But the values vary in the years in between so that a clear trend cannot be identified. Over 80 percent of the wage inequality can be explained by variations between the hierarchy levels whereas less than 20 percent are due to intra-level variations. The wage inequality in the U.S. firm is somewhat higher than in the German firm. ${ }^{15}$ This is in line with the distinctions of wage inequality in Germany and the U.S. in the aggregate (see e.g. Freeman and Katz 1994, Blau and Kahn 1996). Additionally, the share of intra-level wage inequality is more than twice as high than in the German plant. Whereas the absolute amount of inter-level inequality is similar between the two plants, wages differ much more within hierarchy levels in the U.S. plant. ${ }^{16}$ In contrast, wages are attached to jobs and hierarchy levels more significantly in the German plant.

\footnotetext{
${ }^{14}$ The sample size for the U.S. firm is too low in the previous years to get substantial results.

${ }^{15}$ Although we have different observation years for the German and the U.S. plant, wherefore the numbers might be not perfectly comparable, the 1995 overall Theil Index of the U.S. plant (0.112) is still larger than the corresponding value of the German firm. The differences become even clearer using other inequality measures. For example, the person at the $90^{\text {th }}$ percentile of the wage distribution earns twice the amount of the person at the $10^{\text {th }}$ percentile within the German plant, whereas this factor is 3 for the U.S. plant.

${ }^{16}$ This is particular true for the levels 7 and 8 of the U.S plant, where most of the employees are located.
} 
Generally, it is possible to implement monetary incentives by either pay for performance on a certain level of the hierarchy or considerably high wage premiums in connections with promotions. Since the yearly promotion rate is much lower in the German firm as well (see section 4 below), the intensity of competition seems to be much higher in the U.S. plant.

Table 2: Wage inequality in the German and the U.S. plant

\begin{tabular}{|l|c|c|c|c|c|c|}
\hline & \multicolumn{3}{|c|}{ German plant } & \multicolumn{3}{c|}{ U.S. plant } \\
& $\mathbf{1 9 7 5}$ & $\mathbf{1 9 8 5}$ & $\mathbf{1 9 9 5}$ & $\mathbf{1 9 9 6}$ & $\mathbf{1 9 9 7}$ & $\mathbf{1 9 9 8}$ \\
\hline \multirow{2}{*}{ Theil-Index } & 0.075 & 0.095 & 0.100 & 0.126 & 0.149 & 0.142 \\
Inter-Theil & 0.066 & 0.080 & 0.084 & 0.074 & 0.090 & 0.084 \\
& $(88 \%)$ & $(84 \%)$ & $(84 \%)$ & $(59 \%)$ & $(60 \%)$ & $(59 \%)$ \\
Intra-Theil & 0.009 & 0.015 & 0.016 & 0.052 & 0.059 & 0.058 \\
& $(12 \%)$ & $(16 \%)$ & $(16 \%)$ & $(41 \%)$ & $(40 \%)$ & $(41 \%)$ \\
\hline
\end{tabular}

Notes: Theil-Index $=$ Inter-T + Intra-T. Inter-Theil $=$ Part of wage inequality explained by variations between the levels of the hierarchy. Percent of corresponding Theil-Index in parentheses. Intra-Theil = Part of wage inequality explained by variations within the levels of the hierarchy.

Unfortunately, there is no comment of the owners on the reason for the higher intensity of competition in the U.S. firm. Hence, only presumptions can be made: A first possible explanation for this phenomenon is that fears of counter-productive behaviour like mobbing or sabotage against colleagues caused by income disparities are more distinctive for the German firm. Furthermore, the relevance of pay for performance might be higher in the U.S. firm in order to induce extrinsic incentives. In this sense, intrinsic motivation seems to be more relevant for the German firm, whereas intrinsic motivation is of less importance or even crowded out by monetary incentives in the U.S. firm. ${ }^{17}$ Another plausible argument is that collective wage

\footnotetext{
${ }^{17}$ See Frey and Oberholzer-Gee (1997) and Frey and Jegen (2001) for a discussion of possible interactions between extrinsic and intrinsic motivation.
} 
agreements in Germany determine the wages within certain levels of the hierarchy in a stricter way than for the U.S. plant. Lastly, possible data based biases should not be ignored, because the examination of the German plant does not include the whole workforce. On the one, hand the apprentices and the owners are excluded from the analysis. To include these groups would increase the measured wage inequality of this plant (but not the low amount of wage inequality within the levels). On the other hand - as mentioned above - the middle and lower levels of the hierarchy are slightly underrepresented in the analysis of the German firm, which can lead to an overestimation of inequality.

\section{Wage Determinants}

Apart from the hierarchy levels, other characteristics might be responsible for the wages of the employees. Human capital is probably the most popular wage theory. Age, schooling and tenure can be interpreted as proxies for the accumulated human capital of the employees. The importance of these variables compared to the hierarchy levels is estimated with pooled wage regressions with the log of gross monthly wages as the dependent variable. ${ }^{18}$ The wages of different years are deflated with the U.S. and German consumer price index. For both plants three specifications are estimated: First, only the effect of the hierarchy levels on the wage is regarded. Second, the impact of human capital variables and gender is analysed and lastly, a joined estimation of both groups of variables is conducted.

\footnotetext{
${ }^{18}$ The qualitative results hold for panel estimations as well (see Grund and Kräkel 2001: 15-19).
} 
The owners of the two plants are still excluded from the analysis. Level 9, the bestmanned level, is chosen as the base group in the German plant. The results of model (1a) confirm Figure 1. The wages differ considerably between the hierarchy levels. For example, the managers of level 2 earn 40 percent more than the managers of levels 3 and four times more than the workers at level $13 .{ }^{19}$ Each coefficient differs significantly from the wage of the base group (level 9). Worth mentioning is the high value of the adjusted coefficient of determination. The wages are attached to hierarchies (and jobs) to a remarkable degree. The results of model (2a) circumstantiate the relevance of age, tenure and schooling as important wage determinants although the economic relevance of age and tenure is not very high. One additional year of tenure leads to a one percent increase of the wage on average, whereas a concave effect of age is observable. One additional year of schooling raises the wage about 10 percent on average. Controlling for the hierarchy levels simultaneously this effect diminishes to 2.5 percent (see model 3a). Better-qualified employees are placed at higher levels of the hierarchy. Nevertheless, the leveldummies as well as the human capital proxies are significant within the joint regression again. ${ }^{20}$ The sex-dummy - insignificant in model (2a) - shows higher wages for women taking into account the hierarchy level. In this context, the owners declared, though, that men and women fulfil different tasks even on the same level of the hierarchy so that not too much attention should be paid to this result.

\footnotetext{
${ }^{19}$ Note that the coefficients of dummy variables $d$ in semi-logarithmic regressions have to be transformed with $g=\exp (d)-1$ in order to get the relative effect $g$ compared to the base group (see Halvorsen and Palmquist 1980).

${ }^{20}$ The only exemptions are the dummy for level 10 and again the square of tenure.
} 
Table 3: Pooled wage regressions for the German plant

\begin{tabular}{|c|c|c|c|}
\hline Independent variable & (1a) & (2a) & (3a) \\
\hline Intercept & $+8.068 * *(913.3)$ & $+6.479 * * \quad(105.8)$ & $+7.326 * * \quad(220.2)$ \\
\hline Sex (Female) & & -0.016 & $+0.107 * * \quad(13.74)$ \\
\hline Age & & $+0.018 * * \quad(5.58)$ & $+0.020 * * \quad(11.59)$ \\
\hline Age squared $(* 100)$ & & $-0.015 * * \quad(3.55)$ & $-0.024 * * \quad(10.15)$ \\
\hline Tenure & & $+0.010 * * \quad(6.75)$ & $+0.005 * * \quad(6.69)$ \\
\hline Tenure squared $(* 100)$ & & +0.007 & -0.002 \\
\hline Schooling (years) & & $+0.106 * * \quad(51.07)$ & $+0.025 * * \quad(16.72)$ \\
\hline Level-Dummies & & & \\
\hline LEVEL 1 & Excluded & & Excluded \\
\hline LEVEL 2 & $+1.266 * *(99.05)$ & & $+1.085 * * \quad(68.59)$ \\
\hline LEVEL 3 & $+0.931 * *(66.04)$ & & $+0.838 * * \quad(64.71)$ \\
\hline LEVEL 4 & $+0.722 * *(51.56)$ & & $+0.675 * * \quad(53.21)$ \\
\hline LEVEL 5 & $+0.566 * *$ & & $+0.469 * * \quad(33.02)$ \\
\hline LEVEL 6 & $+0.507 * *(37.46)$ & & $+0.441 * * \quad(35.75)$ \\
\hline LEVEL 7 & $+0.211 * *(24.94)$ & & $+0.209 * * \quad(27.46)$ \\
\hline LEVEL 8 & $+0.298 * *(28.17)$ & & $+0.281 * * \quad(29.33)$ \\
\hline LEVEL 9 & Base group & & Base group \\
\hline LEVEL 10 & $-0.017^{*} \quad(2.51)$ & & -0.010 \\
\hline LEVEL 11 & $-0.087 * *(14.04)$ & & $-0.104 * * \quad(18.30)$ \\
\hline LEVEL 12 & $-0.150 * *(20.43)$ & & $-0.116^{* *} \quad(17.27)$ \\
\hline LEVEL 13 & $-0.133 * *(13.47)$ & & $-0.110 * * \quad(12.35)$ \\
\hline Year dummies & Yes & Yes & Yes \\
\hline $\mathrm{R}_{\text {adj. }}^{2}$ Observations & \begin{tabular}{|ll}
0.767 & \\
& 5781 \\
\end{tabular} & \begin{tabular}{|ll}
0.472 & \\
& 5781
\end{tabular} & \begin{tabular}{|ll}
0.855 & \\
& 5781
\end{tabular} \\
\hline
\end{tabular}

Notes: * significant at the $5 \%$-level, ** significant at the $1 \%$-level. Absolute T-values in parentheses.

The same three specifications are computed for the U.S. plant with the exemption that no information for years of schooling is available. Again, all level dummies are highly significant (model $1 \mathrm{~b}$ ). The top-manager (level 1) received a monthly wage, which overtops the wages of the employees of level 2 with 57 percent and the wages of the employees at the lowest level with the septuple for instance. The adjusted coefficient of determination is somewhat lower for the U.S. plant, which is in line with the observation that intra-level wage inequality plays a more decisive role in this firm. Tenure is of higher and age of less relevance for the determination of wages in 
the U.S. plant (see model 2b). ${ }^{21}$ Again within the combined estimation (model 3b) the size of the coefficients declines because of the positive correlation between human capital and hierarchical position. But the significance remains in nearly all cases. For the U.S. also applies that the tasks of men and women are different within the levels. Even so, the fact that women earn approximately 30 percent less than men - even controlling for levels and human capital proxies - is somewhat astonishing. Direct wage discrimination cannot be ruled out.

Table 4: Pooled wage regressions for the U.S. plant

\begin{tabular}{|c|c|c|c|}
\hline Independent variable & (1b) & $(2 b)$ & $(3 b)$ \\
\hline Intercept & $+7.654 *(324.5)$ & $+7.088^{* *} \quad(75.42)$ & $+7.292 * * \quad(96.73)$ \\
\hline Sex (Female) & & $-0.409 * * \quad(14.21)$ & $-0.346 * * \quad(14.53)$ \\
\hline Age & & $+0.013 * \quad(2.48)$ & $+0.010^{*} \quad(2.44)$ \\
\hline Age squared $(* 100)$ & & -0.001 & -0.004 \\
\hline Tenure & & $+0.039 * *$ & $+0.022 * *$ \\
\hline Tenure squared $(* 100)$ & & $-0.100 * * \quad(5.36)$ & $-0.055^{* *}$ \\
\hline Level-Dummies & & & \\
\hline LEVEL 1 & $+1.215 * * \quad(21.05)$ & & $+1.027 * * \quad(20.17)$ \\
\hline LEVEL 2 & $+0.761 * * \quad(16.92)$ & & $+0.618 * * \quad(15.68)$ \\
\hline LEVEL 3 & $+0.521 * * \quad(15.59)$ & & $+0.373 * * \quad(12.55)$ \\
\hline LEVEL 4 & $+0.337 * * \quad(10.39)$ & & $+0.266 * * \quad(9.06)$ \\
\hline LEVEL 5 & $+0.119 * * \quad(4.36)$ & & +0.039 \\
\hline LEVEL 6 & -0.056 & & +0.030 \\
\hline LEVEL 7 & Base group & & Base group \\
\hline LEVEL 8 & $-0.170 * * \quad(7.57)$ & & $-0.109^{* *} \quad(5.24)$ \\
\hline LEVEL 9 & $-0.482 * * \quad(9.42)$ & & $-0.384 * * \quad(8.46)$ \\
\hline LEVEL 10 & $-0.636 * * \quad(6.33)$ & & $-0.502 * * \quad(5.75)$ \\
\hline Year dummies & Yes & Yes & Yes \\
\hline $\begin{array}{l}\mathrm{R}_{\text {adj. }}^{2} \\
\quad \text { Observations }\end{array}$ & $\begin{array}{ll}0.541 & \\
& 1266\end{array}$ & $\begin{array}{ll}0.423 & \\
& 1266\end{array}$ & $\begin{array}{ll}0.662 & \\
& 1266\end{array}$ \\
\hline
\end{tabular}

Notes: * significant at the $5 \%$-level, ** significant at the $1 \%$-level. Absolute T-values in parentheses.

\footnotetext{
${ }^{21}$ The lower age-effect might be influenced by the absence of the schooling variable. If younger employees have received more schooling and schooling is a relevant wage determinant, the coefficient might be biased downwards.
} 
Recapitulating, the size of the adjusted $\mathrm{R}^{2}$ is striking especially for the level regression of the German firm (model 1a). Hence, wages are attached to levels probably in consequence of collective wage agreements, which leads to the implicit result that ability and effort do not play an important role for the wage setting within the German plant. Their relevance seems to be more important within the U.S. firm, where strict regulations with respect to the wage setting do not exist. There is an additional hint in the data that this might be a reasonable explanation: In single years, either almost every or hardly any employee receives real wage increases within the German plant. In contrast, the fraction of employees with real wage increases varies from 50 to 80 percent within the U.S. firm.

\section{Promotion Rates and Wage Premiums of Promotions - Comparative Discussion with Prior Studies}

The results presented in the prior section bear articulate differences between the wage policy of the German and the U.S. firm. It has turned out that there are much smaller monetary incentives in the German firm. Hence, it seems to be useful to compare the results with the findings of prior studies in order to find out possible coherences in the implementation of monetary incentives between different firms. In particular, the implemented incentive effects of promotions in different firms are compared in the following. Generally, the employers have two parameters to induce incentives from promotions: $:^{22}$ First, the manipulation of the yearly promotion rate and second, the determination of the wage premium of promotions. The yearly promotion rate is partly influenced by the number of vacancies during a year, which is among other things determined by the growth of the firm, the employee turnover rate and the age structure of the work force. Nevertheless, the employer is able to influence this factor for instance by setting the hiring policy of the firm in the direction of mainly external recruitment or internal promotions. The wage premium of promotions is defined as

\footnotetext{
${ }^{22} \mathrm{~A}$ promotion is defined as a movement to an upper level of the hierarchy in the following.
} 
the wage increase of promoted employees in a certain year minus the wage increase of non-promoted employees in that year. The employer's freedom to influence this factor is still stronger. Her interference is sure enough restricted by wage agreements with unions in some cases and then, wages are attached to jobs, so that the job holder is paid with respect to his job description. But even in these cases many employers pay their employees more than the collectively negotiated wage, which merely fix the minimum wage for a certain job.

The incentive effect of the wage premium of promotions is unambiguous. The higher the amount of the wage premium the more explicit the incentive for the employees to make an effort to attain the promotion. The effect of the yearly promotion rate is not so clear. A necessary condition for a significant incentive effect consists in promotion decisions that are based on performance and not on seniority, for instance. There are no incentives with a promotion rate of zero and one, either. From a theoretical point of view, the marginal probability to win a promotion tournament is the decisive factor to determine the effort choice of the employee. Orrison et al. (1997), as well as Harbring and Irlenbusch (2002) derive for a tournament model with identically distributed individual error terms that effort choice is even independent of the fraction of winner prizes in a symmetric equilibrium. But experimental evidence hints that employees' maximal efforts occur at a fraction of winner prizes of 0.5 compared to tournaments with only few winner or loser prizes (see Orrison et al. 1997: Table 3, Harbring and Irlenbusch 2002). This is also the result of the theory of achievement motivation, which was already developed half a century ago by psychologists (see e.g. Atkinson 1964). In this sense the amount of achievement motivation for a given task is influenced by the product of the probability of success $(P)$ and the incentive value of success $(I)$, which is defined as $I=1-P$. In this situation motivation is strongest, when a task appears to be one of intermediate difficulty, i.e. $P=0.5$. Hence, in a firm with a yearly promotion rate of 10 percent for instance, incentives could be raised by increasing the promotion rate. Since yearly promotion rates are usually far below 0.5 in practise, higher promotion rates lead to higher incentives. 
As a consequence, wage premiums of promotion and yearly promotion rates can be supposed to be substitutes for personnel policy in order to form incentives. For empirically relevant cases, there should be an inverse relationship between these two variables. If there is only a very small chance for a promotion of a certain employee, he has to be encourage to work hard with a considerably high wage premium.

The comparison of the results of the German and the U.S. plant in this study with the results of Baker et al. (1994a) and Treble et al. (2001) in regard to the yearly promotion rate and the wage premium of promotions shows first of all very low promotion opportunities in the German firm (see Table 5). As mentioned above, monetary incentives are very limited in this plant and the German institutional framework differs considerably from the British as well as the U.S. system. Focussing on the other three firms gives a hint for the relevance of the inverse relationship between promotion rate and wage premium in reality. Within the U.S. plant of our study (the firm analysed by Baker et al.) we see that the yearly rate of promotion is the lowest (highest), while the wage premium of promotions is the highest (lowest). ${ }^{23}$ Surely, the number of observations is far too small to derive statistically significant correlations and other determinants might influence the varying values of the firms as well. Unfortunately, other studies do not provide the necessary information, though. ${ }^{24}$ Additional evidence shows that promotion rates are declining with higher levels and with duration of affiliation to a certain level (see Baker et a. 1994a: 902 and Treble et al. 2001: 541).

\footnotetext{
${ }^{23}$ Leonard (1990: 27-S) confirms the inverse relationship between wage premiums of promotions and promotion rates for executives of about 500 large U.S. firms.

${ }^{24}$ Another recent study from Lima and Pereira (2001), which uses a matched employer-employee panel of 74 Portuguese firms from the manufacturing sector, presents with regard to this question only aggregate results (promotion rate of 0.15 , wage premium of +0.02 ). The definition of a promotion is the employers' choice in this data set, which means that promotions are not necessarily identical with moves to an upper level of the hierarchy in this study. Only 4 percent of the employees of these firms move to an upper level on average each year.
} 
Table 5: Wages, Promotions, and Hierarchies in Different Firms

\begin{tabular}{|l|c|l|c|c|c|}
\hline & $\begin{array}{c}\text { Observation } \\
\text { period }\end{array}$ & Industry & $\begin{array}{c}\text { Number } \\
\text { of levels }\end{array}$ & $\begin{array}{c}\text { Yearly } \\
\text { promotion } \\
\text { rate }\end{array}$ & $\begin{array}{c}\text { Wage } \\
\text { premium of } \\
\text { promotions }\end{array}$ \\
\hline German plant & $1975-1995$ & Manufacturing & $12^{(\mathrm{b})}$ & 0.012 & +0.122 \\
U.S. plant & $1978-1998$ & Manufacturing & 10 & 0.084 & +0.157 \\
\hline $\begin{array}{l}\text { Treble et al. (2001) } \\
\text { (British firm) }\end{array}$ & $1989-1997$ & Service sector & 12 & 0.125 & +0.119 \\
\hline $\begin{array}{l}\text { Baker et al. (1994) } \\
\text { (U.S. firm) }\end{array}$ & $1969-1988$ & Service sector & 8 & 0.145 & +0.058 \\
\hline
\end{tabular}

Notes: (a) Wage increase of promoted employees in a certain year minus wage increase of non-promoted employees in that year. (b) Strictly speaking, there are two more hierarchy levels in this German plant, but the owners, who are the managing directors simultaneously, are deleted from the analysis, as well as the apprentices.

From a theoretical point of view, the number of upper levels is an additional influencing factor for inducing incentives for employees because of the option value of additional promotions in the future (see Rosen 1986): The larger the number of levels, the bigger are the chances to get several promotion-based wage increases. But a larger number of hierarchy levels does not necessarily increase incentives significantly in reality. Frequently, there are intra-firm "dead ends" of predetermined career ladders or "glass ceilings", in the sense that most employees have no chance to be promoted higher than a certain level, e.g. because of lacking formal qualifications. This is particularly true for the German plant of this study. The few promotions are concentrated on the bottom six levels in this plant. Hence, the fact that there are more levels in the German plant than in the U.S. plant should have no incentive effect, since the blue-collar workers have no chance at all to be promoted to a management level. 


\section{Conclusion}

Analysing the wage policy of a German and a U.S. firm, convex hierarchical wage profiles can be found in both firms. Still, there are remarkable differences between the two firms. Only very small monetary incentives exist within the German firm. Both, wage inequality within certain levels of the hierarchy and yearly promotion rates are very low. Wages are attached to hierarchy levels very explicitly in the German plant. In contrast, the policy of the U.S. plant induces much more incentives. Considerably high intra-level wage variations, wage premiums with promotions and yearly promotion rates lead to a higher intensity of competition. The results hint to the presumption that the institutional environment influences the personnel policy of firms. In the German plant the owners' policy is restricted by institutions like collective wage agreements, for example. With this study additional light is shed on the frequently complained "black box" of the firm. But, as the discussion of section 4 shows, further data and work is necessary to enlighten the procedures inside the firm completely. 


\section{References}

Ariga, K.; Y. Ohkusa; G. Brunello (1999): Fast Track: Is It in the Genes? The Promotion Policy of a Large Japanese Firm, in: Journal of Economic Behavior \& Organization (38), 385-402.

Atkinson, J.W. (1964): An Introduction to Motivation. Princeton.

Baker, G.; B. Holmström (1995): Internal Labor Markets: Too Many Theories, Too Few Facts, in: American Economic Review Paper and Proceedings (85), 255259.

Baker, G.; M. Gibbs; B. Holmström (1993): Hierarchies and Compensation, in: European Economic Review (37), 366-378.

Baker, G.; M. Gibbs; B. Holmström (1994a): The Internal Economics of the Firm: Evidence from Personnel Data, in: Quarterly Journal of Economics (109), 881919.

Baker, G.; M. Gibbs; B. Holmström (1994b): The Wage Policy of a Firm, in: Quarterly Journal of Economics (109), 921-955.

Becker, G. S. (1962): Investment in Human Capital: A Theoretical Analysis, in: Journal of Political Economy (70), Supplement, 9-49.

Becker, G.S.; G. J. Stigler (1974): Law Enforcement, Malfeasance, and Compensation of Enforcers, in: Journal of Legal Studies (3), 1-18.

Blau, F. D.; L. M. Kahn (1996): International Differences in Male Wage Inequality: Institutions versus Market Forces, in: Journal of Political Economy (104), 791837.

Brüderl, J. (1992): Dynamic Career Models and Inequality Research: A Reexamination of the Sorensen Model, in: Sociological Methods and Research (21), 3-24.

Brüderl, J.; A. Diekmann; P. Preisendörfer (1991): Patterns of Intraorganizational Mobility: Tournament Models, Path Dependency, and Early Promotion Effects, in: Social Science Research (20), 197-216.

Brüderl, J.; P. Preisendörfer; R. Ziegler (1993): Upward Mobility in Organizations: The Effect of Hierarchy and Opportunity Structure, in: European Sociological Review (9), 173-188.

Calvo, G.A. (1987): The Economics of Supervision, in: Nalbantian, H.R. (ed.): Incentives, Cooperation, and Risk Sharing, Totowa, 87-103.

Calvo, G.A./Wellisz, S. (1979): Hierarchy, Ability, and Income Distribution, in: Journal of Political Economy (87), 991-1010.

Chiappori, P. A., B. Salanie, J. Valentin (1999): Early Starters versus Late Beginners, in: Journal of Political Economy (87), 991-1010.

Doeringer, P. B.; M. J. Piore (1971): Internal Labor Markets and Manpower Analysis. Lexington.

Flabbi, L.; A. Ichino (2001): Productivity, Seniority and Wages: New Evidence from Personnel Data, in: Labour Economics (8), 359-387.

Freeman, R. B.; L. F. Katz (1994): Rising Wage Inequality: The United States vs. other Advanced Countries, in: Freeman, R. B. (ed.): Working under Different Rules, New York, 29-62. 
Frey, B. S.; F. Oberholzer-Gee (1997): The Cost of Price Incentives: An Empirical Analysis of Motivation Crowding-out. American Economic Review (87), 746755.

Frey, B. S.; R. Jegen (2001): Motivation Crowding Theory. Journal of Economic Surveys (15), 589-611.

Grund, C.; M. Kräkel, Interne Arbeitsmärkte und betriebliche Entgeltstrukturen - eine empirische Untersuchung, in: Albach H. (ed.): Personalmanagement 2001 (Zeitschrift für Betriebswirtschaft Ergänzungsheft 1/2001), 1-25.

Halvorsen, R.; R. Palmquist (1980): The Interpretation of Dummy Variables in Semilogarithmic Equations, in: American Economic Review (70), 474-475.

Harbring, C.; B. Irlenbusch (2002): Anreize zu produktiven und destruktiven Anstrengungen durch relative Entlohnung. Mimeo.

Kanemoto, Y.; W. B. MacLeod (1991): The Theory of Contracts and Labor Practices in Japan and the United States, in: Managerial and Decision Economics (12), 159-170.

Lazear, E. P. (1979): Why is there Mandatory Retirement?, in: Journal of Political Economy (87), 1261-1284.

Lazear, E. P. (1992): The Job as a Concept, in: Bruns, W. J. (ed.): Performance Measurement, Evaluation, and Incentives, Boston, 183-215.

Lazear, E. P. (1999): Personnel Economics: Past Lessons and Future Directions, in: Journal of Labor Economics (17), 199-236.

Lazear, E. P. (2000): Performance Pay and Productivity, in: American Economic Review (90), 1346-1361.

Lazear, E. P.; S. Rosen (1981): Rank-Order Tournaments as Optimum Labor Contracts, in: Journal of Political Economy (89), 841-864.

Leonard, J. S. (1990): Executive Pay and Firm Performance, in: Industrial and Labor Relations Review (43), 13-S-29-S.

Lima, F.; P.T. Pereira (2001): Careers and Wage Growth within Large Firms. IZADiscussion Paper No. 336.

Medoff, J.; K. Abraham (1980): Experience, Performance, and Earnings, in: Quarterly Journal of Economics (95), 703-736.

Orrison, A.; A. Schotter ; K. Weigelt (1997) : On the Design of Optimal Organizations Using Tournaments : An Experimental Examination. New York University, C.V. Starr Working Papers, No. 97-26.

Ransom, M. R.; R. L. Oaxaca (2002): Intrafirm Mobility and Sex Differences in Pay. Mimeo.

Rosen, S. (1986): Prizes and Incentives in Elimination Tournaments, in: American Economic Review (76), 701-715.

Seltzer, A.; D. Merrett (2000): Personnel Policies at the Union Bank of Australia: Evidence from the 1888-1900 Entry Cohorts, in: Journal of Labor Economics (18), 573-613.

Shorrocks, A.F. (1980): The Class of Additively Decomposable Inequality Measures, in: Econometrica (48), 613-625.

Theil, H. (1967): Economics and Information Theory. Amsterdam.

Treble, J.; E. van Gameren; S. Bridges; T. Barmby (2001): The Internal Economics of the Firm: Further Evidence from Personnel Data, in: Labour Economics (8), 531-552. 


\section{IZA Discussion Papers}

\begin{tabular}{|c|c|c|c|c|}
\hline No. & Author(s) & Title & Area & Date \\
\hline 589 & $\begin{array}{l}\text { Š. Jurajda } \\
\text { K. Terrell }\end{array}$ & $\begin{array}{l}\text { Job Growth in Early Transition: Comparing Two } \\
\text { Paths }\end{array}$ & 4 & $09 / 02$ \\
\hline 590 & $\begin{array}{l}\text { H. Görg } \\
\text { E. Strobl } \\
\text { F. Walsh }\end{array}$ & $\begin{array}{l}\text { Why Do Foreign-Owned Firms Pay More? } \\
\text { The Role of On-the-Job Training }\end{array}$ & 2 & $10 / 02$ \\
\hline 591 & $\begin{array}{l}\text { H. Görg } \\
\text { E. Strobl }\end{array}$ & $\begin{array}{l}\text { Spillovers From Foreign Firms Through Worker } \\
\text { Mobility: An Empirical Investigation }\end{array}$ & 1 & $10 / 02$ \\
\hline 592 & J. Wagner & $\begin{array}{l}\text { Testing Lazear's Jack-of-All-Trades View of } \\
\text { Entrepreneurship with German Micro Data }\end{array}$ & 5 & $10 / 02$ \\
\hline 593 & $\begin{array}{l}\text { T. K. Bauer } \\
\text { P. J. Dross } \\
\text { J. P. Haisken-DeNew }\end{array}$ & Sheepskin Effects in Japan & 1 & $10 / 02$ \\
\hline 594 & $\begin{array}{l}\text { S. C. Wolter } \\
\text { M. Coradi Vellacott }\end{array}$ & $\begin{array}{l}\text { Sibling Rivalry: A Look at Switzerland with PISA } \\
\text { Data }\end{array}$ & 2 & $10 / 02$ \\
\hline 595 & $\begin{array}{l}\text { W. Arulampalam } \\
\text { A. L. Booth } \\
\text { M. L. Bryan }\end{array}$ & $\begin{array}{l}\text { Work-Related Training and the New National } \\
\text { Minimum Wage in Britain }\end{array}$ & 3 & $10 / 02$ \\
\hline 596 & $\begin{array}{l}\text { H. Görg } \\
\text { E. Strobl }\end{array}$ & $\begin{array}{l}\text { Relative Wages, Openness and Skill-Biased } \\
\text { Technological Change }\end{array}$ & 2 & $10 / 02$ \\
\hline 597 & $\begin{array}{l}\text { S. M. Fuess, Jr. } \\
\text { M. Millea }\end{array}$ & $\begin{array}{l}\text { Disentangling Pay and Productivity in a } \\
\text { Corporatist Economy: The Case of Germany }\end{array}$ & 5 & $10 / 02$ \\
\hline 598 & $\begin{array}{l}\text { D. Del Boca } \\
\text { A. Lusardi }\end{array}$ & $\begin{array}{l}\text { Credit Market Constraints and Labor Market } \\
\text { Decisions }\end{array}$ & 2 & $10 / 02$ \\
\hline 599 & $\begin{array}{l}\text { H. N. Mocan } \\
\text { B. Scafidi } \\
\text { E. Tekin }\end{array}$ & Catholic Schools and Bad Behavior & 5 & $10 / 02$ \\
\hline 600 & $\begin{array}{l}\text { J. S. Lauerová } \\
\text { K. Terrell }\end{array}$ & $\begin{array}{l}\text { Explaining Gender Differences in Unemployment } \\
\text { with Micro Data on Flows in Post-Communist } \\
\text { Economies }\end{array}$ & 4 & $10 / 02$ \\
\hline 601 & $\begin{array}{l}\text { Š. Jurajda } \\
\text { K. Terrell }\end{array}$ & $\begin{array}{l}\text { What Drives the Speed of Job Reallocation } \\
\text { During Episodes of Massive Adjustment? }\end{array}$ & 5 & $10 / 02$ \\
\hline 602 & L. Locher & Migration in the Soviet Successor States & 2 & $10 / 02$ \\
\hline 603 & $\begin{array}{l}\text { T. Andrén } \\
\text { B. Gustafsson }\end{array}$ & $\begin{array}{l}\text { Income Effects from Labor Market Training } \\
\text { Programs in Sweden During the 80's and 90's }\end{array}$ & 2 & $10 / 02$ \\
\hline 604 & $\begin{array}{l}\text { S. P. Jenkins } \\
\text { C. Schluter }\end{array}$ & $\begin{array}{l}\text { The Effect of Family Income During Childhood on } \\
\text { Later-Life Attainment: Evidence from Germany }\end{array}$ & 5 & $10 / 02$ \\
\hline 605 & C. Grund & $\begin{array}{l}\text { The Wage Policy of Firms - Comparative } \\
\text { Evidence for the U.S. and Germany from } \\
\text { Personnel Data }\end{array}$ & 5 & $10 / 02$ \\
\hline
\end{tabular}

An updated list of IZA Discussion Papers is available on the center's homepage www.iza.org. 